\title{
Effects of age on the acquisition of agreement inflection
}

\section{EIma Blom · Daniela Polišenská · Fred Weerman}

Published online: 30 October 2007

(C) Springer Science+Business Media B.V. 2007

\section{Erratum to: Morphology (2006) 16:313-336 DOI 10.1007/s11525-007-9110-1}

The original version of this article unfortunately contained a mistake. On p. 326, in Table 5 the data were misplaced. The corrected table is given below.

Table 5 Probabilities of substitution of suffixes $-e n,-t$ and $-\varnothing$ (excl. root infinitives)

\begin{tabular}{lcll}
\hline $\begin{array}{l}\text { Substitute } \\
\text { Context }\end{array}$ & $-\varnothing$ & $\begin{array}{l}-\mathrm{t} \\
\text { 1SG, PL }\end{array}$ & \multicolumn{2}{c}{ SG } \\
\hline Child L1 $^{\text {a }}$ & $2 / 3 \mathrm{SG}, \mathrm{PL}$ & $3.5 \% n=175$ & $0 \% \quad n=262$ \\
Child L2 Turkish & $2 \% n=239$ & $4 \% \quad n=116$ & $0 \% \quad n=134$ \\
Child L2 Moroccan & $5 \% n=194$ & $9 \% \quad n=192$ & $2 \% \quad n=272$ \\
Adult L2 Turkish & $32 \% n=136$ & $8 \% \quad n=83$ & $19 \% \quad n=113$ \\
Adult L2 Moroccan & $24 \% n=335$ & $8 \% \quad n=188$ & $28 \% \quad n=275$ \\
\hline
\end{tabular}

\footnotetext{
a The scores of child L1 are only from 3 to 5 years old population. The 6-year-old group reached ceiling levels for verbal inflection and was therefore not included in the error analysis
}

The online version of the article can be found under doi: 10.1007/s11525-007-9110-1

E. Blom · D. Polišenská · F. Weerman

Amsterdam Center for Language and Communication, University of Amsterdam, 1012 VB Amsterdam, The Netherlands

E. Blom $(\bowtie)$

Faculty of Humanities, Department of Dutch Studies, University of Amsterdam, Spuistraat 134, 1012 VB Amsterdam, The Netherlands e-mail: w.b.t.blom@uva.nl 